\title{
CAPITALISM AND SOCIALISM AS IDEOLOGICAL CONSTRUCTIONS IN AMERICAN DYSTOPIAN NOVELS
}

\author{
Anna Sriastuti \\ Universitas Kristen Satya Wacana \\ e-mail: anna.sriastuti@uksw.edu \\ Ida Rochani Adi \\ Universitas Gadjah Mada \\ e-mail: idaadi@ugm.ac.id \\ Muh. Arif Rokhman \\ Universitas Gadjah Mada \\ e-mail: arokhman@ugm.ac.id
}

\begin{abstract}
Literature reflects the history of people's lives, which includes lifestyle, culture, language, desires, and important events in people's lives. Dystopia novels cannot be separated from discussions about authoritarian government, restraints on people's freedom, criticism of the development of technology and information, exploitation and the class system, and the arbitrariness of the rulers. Despite telling a bad world, Dystopian novels proved popular in America, a country that promised freedom, equality, and freedom to its citizens. The possibility of different realities captured by American popular novelists who differ from their imaginations gave birth to dystopian novels that are popular in American society. Thus, this study is important to analyse Capitalism and Socialism as ideological constructions in American dystopian novels through Fahrenheit 451, The Handmaid's Tale, Uglies, and The Hunger Games. This research will formulate an understanding of whether or not American dystopian novels confirm or negate the ideology of Capitalism and the ideology of Socialism.
\end{abstract}

Keywords: capitalism; dystopia; ideology; literature; socialism

DOI $\quad$ : https://doi.org/10.22146/rubikon.v8i2.69733

Available at https://jurnal.ugm.ac.id/rubikon/article/view/69733

This work is licensed under a Creative Commons Attribution-ShareAlike 4.0 International License

\section{INTRODUCTION}

Literature is a part of human life. The journey of the American nation is also recorded in American literature. American
Article information

Received: 10 August, 2021

Revised: 18 August, 2021

Accepted: 01 September, 2021

literature tells the story of the journey of the American people since the Puritans came and left the Americas, which was influenced by a combination of myths brought by the first 
Europeans from their homelands and new myths that they acquired in new lands, the historical journey of the American people, and the thoughts of the nation. The authors of early American literature recounted in their literature that this new land had the qualities of a "promised land" that promised a better life for a chosen nation or "God's Chosen People". Thus, Utopia literature in America is influenced by the American dream or what is known as the American Dream, which writer James Truslow Adams in his Epic of America (1931) described as a dream about a better, richer for everyone, with opportunities for each according to his abilities or achievements.

Thoughts about cracks in utopian thinking occurred also at the end of the 19th century which was a resistance to the central utopian concept of a perfect life. Between 1870 and 1910, a new middle class developed in the United States, and for this class and its supporters an entirely new ideology was needed. This new middle class is not a class of property holders. Its members are the proletariat, which are managers, engineers, professional bureaucrats, and technicians of all kinds. To these people, Puritan moralism and the Puritan social and political order so long admired were deemed incompatible with the new rationalized order. American Puritanism has been identified with a particular set of attitudes toward material success, emphasizing industry and the pursuit of wealth, thereby creating a widening social gap between the rich and the poor. Such an ethic, creates a living modern Capitalism, which is the true protection of the entire economic and social order. Besides, various events that attacked America such as war, economic crisis, and terrorist attacks faded Utopia thinking and brought the Utopia trend to the Dystopian trend occurred at the end of the 19th century.

Narratives about Capitalism and Socialism have been the subject of reflection and have been put into literary works by American literary writers since the late 1800s. In this year, Utopia writers or known as conservative Utopias such as Arthur Bird Looking Forward, Dream of the United States in 1999 narrated America as a world role model and therefore American Capitalism must be spread throughout the world. A dystopian novel, Piano Player (1952), depicts America as a state version of Capitalism, in which the state functions as a corporation that controls the means of production. The supercomputer, EPICAC XIV, runs the economy, and machines eliminate the need for human labour. This led the workers at Ilium to try to destroy the machines that had replaced them and humiliated them. However, due to manipulation and propaganda about the importance of technology, these workers abandoned their revolution and started rebuilding machines. As a result, they recreate the conditions that allow the upper class to maintain its power in society. At the same time that socialist thought emerged in the midst of labour strife and anarchist violence, The Republic of the Future (1887) was a Dystopian satire depicting a socialist society in which every trace of inequality has been carefully removed. In this novel, technological advances have created the possibility of material abundance with minimal labour requirements.

The successful revolution in America at the end of the nineteenth century had brought the socialists to power and were able to transform economic and social life to fulfil their egalitarian ideals. But after a century and a half of Socialism successfully eradicated 
competition and inequality, creativity and innovation became paralyzed. Socialism which is predicted to be better than Capitalism is in fact inseparable from the control system of the rulers which is nothing but the hallmark of Capitalism. The ideological contradiction of Capitalism and Socialism also continues to be an interesting debate in America, which is expressed in American dystopian novels in the following years.

This study in aimed to analyse Capitalism and Socialism as ideological constructions in American dystopian novels. The novels in this study are Fahrenheit 451, The Handmaid's Tale, Uglies, and The Hunger Games. The twists of these two ideologies are conveyed by the author through story narratives and conflicts in the novel.

\section{Capitalism Ideology}

The term "capitalist", which means owner of capital, appears earlier than the term "capitalism" and dates back to the mid-17th century. "Capitalism" comes from the word capital, which evolved from capitale, a late Latin word based on caput, meaning "head", which is also the origin of "movable property" and "livestock" in the sense of movable property. Capitale appeared in the 12th to 13th centuries to refer to a fund, stock of merchandise, amount of money or money that carries interest or profit. In 1283, the term referred to wealth, money, funds, goods, assets, property, and so on. Capitalism is an economic system based on ownership of capital to control production and earn profits (Zimbalist, 1988). The main characteristics of Capitalism include private or group ownership, capital accumulation, labour wages, price systems and competitive markets. In a capitalist market economy, the owners of capital are the determinants of production and investment policies even though the prices and distribution of goods and services are determined by competition in the market.

The earliest use of the term "Capitalism" in its modern sense is attributed to Louis Blanc in 1850 who referred to the appropriation of capital by some to the exclusion of others and Pierre-Joseph Proudhon in 1861 who referred to an economic and social regime in which capital, sources of income, generally not owned by those who make it work through their labour. Karl Marx and Friedrich Engels referred to the "capitalist system" and to the "capitalist mode of production".

Capitalism according to Karl Marx is characterized by the division of labour and the means of production, private ownership of the means of production, legal freedom of workers, generalization of production, and the exchange of goods. The asymmetry of power is embedded in the system because it is created by three agents: pure workers, owners of the means of production, and owners of natural resources. Meanwhile, workers take part in the production process to earn wages which they will use for consumption, and natural resource owners tend to increase their income to buy luxury goods. The goal of the capitalist is the maximum expansion of capital or capital in competition with other capitalists. The way the owner of capital to achieve this goal is to maximize profits, namely to maximize the difference in the value of the goods sold and the value of the means of production used (Marx, 1993).

Critics of Capitalism argue that Capitalism establishes power in the hands of the existing minority capitalist class through the exploitation of the majority working class 
and their labour; prioritize profits over social goods, natural resources and the environment. They lead to inequality, corruption and economic instability. Proponents of Capitalism argue that it provides better products and innovations through competition, promotes pluralism and decentralization of power, spreads wealth to all productive people who then invests in useful enterprises based on market demand, enables flexible incentive systems where efficiency and sustainability are priorities to protect capital, create strong economic growth and generate productivity and prosperity that greatly benefit society. In a capitalist system, although the government protects private property and guarantees the right of citizens to choose their jobs, it also does not prevent companies from determining the wages they will pay and the prices they will charge for their products. At the urging of capitalists, many countries have minimum wage laws and minimum safety standards. Under some versions of capitalism, large corporations can form almost monopolies in some industries. In many countries, public utilities such as electricity, materials heating, fuel and communications can operate as monopolies under government regulation because of the high economies of scale. Government agencies set service standards in many industries, such as airlines and broadcasting, and fund programs. In addition, governments regulate capital flows and use financial tools such as interest rates to control factors such as inflation and unemployment (Baptist \& Hyman, 2014).

The influence of technological developments is another issue related to Capitalism. Technologies designed to cut labour costs will create permanent unemployment. Since these social and ecological challenges arise from the tremendous power of technology, they can be seen as a side effect of socialist and capitalist growth (Boldizzoni, 2020).

\section{Socialism Ideology}

Socialism, which comes from the word socius or society, emerged in the late 18th and early 19th centuries. This ideology emerged as a reaction to the ideology of Capitalism which caused the industrial revolution in England because of the disparity between the bourgeoisie (owners of capital) who had a high standard of living and the proletariat (workers) who had a low standard of living due to their low salary. With the emergence of the Social Revolution, the ideology of Socialism emerged which is a political, social, and economic philosophy that includes various economic and social systems characterized by social ownership of the means of production and workers. It includes the political theories and movements associated with such a system. Social ownership can be public, collective, cooperative, or equity. Although there is no single definition that encapsulates the many types of Socialism, social ownership is one element in common (Busky, 2000).

Socialists have applied the ideals and principles of equality, democracy, individual freedom, self-realization, and community or solidarity. Regarding equality, they have proposed a strong version of the equality of opportunity principle according to which everyone should broadly have equal access to the material and social means necessary to lead a thriving life (Wright, 2010). Socialists also embrace democratic ideals, which require that people have equal access to the necessary means to participate meaningfully in the decisions that affect their lives (Wright, 2010). Many socialists say that democratic 
participation should be available not only at the level of government institutions, but also in various economic arenas, such as within companies.

Socialists are also committed to the importance of individual freedom from domination to self-determination and benefit from that choice. Individual freedom is believed to be able to foster creativity and productivity to be able to contribute to society (Elster, 1986). Socialists often emphasize the idea of community or solidarity so that they regard the interests and welfare of others as important. People must recognize the positive duty of supporting others, or, as Einstein (1949) put it, a sense of responsibility for others. Or, as Cohen puts it, people should care, and, if necessary and possible, care for each other, and also care that they care for each other. Community is sometimes presented as a moral ideal which is not in itself a demand for justice but can be used to dampen the problematic outcomes permitted by some demands of justice (such as the inequalities of outcomes permitted by the luckegalitarian principle of equality of opportunity (Cohen 2009). However, community is sometimes presented in the socialist view as a demand for justice itself. Some socialists also take solidarity as partly shaping the desired form of social freedom in which people can not only advance their own good but also to act with and for others.

Mark (2016) mentions that Capitalism persists in American society because in a capitalist economy, incentives are the most important. This is what makes Capitalism persist, meanwhile, socialism tends to fail because under socialism, incentives play a minimal role or are ignored altogether.
The theory of Capitalism and Socialism is an important part of this research. Capitalism is confronted with Socialism because the two ideologies are contradictory in terms of property, class system, and exploitation. These three values are also presented by the author in American dystopian novels. Thus, the theory of Capitalism and Socialism can be used to answer the first research questions about ideology in American popular literature through American dystopian novels.

\section{DISCUSSION}

This study presents a discussion of Capitalism and Socialism as the ideological constructions of Fahrenheit 451, The Handmaid's Tale, Uglies, and The Hunger Games novels. The main characteristics of Capitalism which include private or class ownership, capital accumulation, labour wages, price systems and competitive markets for profit by policy makers are continuously presented in these dystopian novels. (Zimbalist, 1988; Hyman \& Baptist, 2014). In addition to Capitalism, an economic and social system characterized by social ownership of the means of production and workers as the hallmark of Socialism is also presented in these American dystopian novels. In the conflict between Capitalism and Socialism, the arena of contestation lies in property, class system, and exploitation (Zimbalist, 1998). In the dystopian novels usen in this study, the opposite of these two ideologies is conveyed by the author through story narratives and conflicts in the novel.

\section{Ownership as an Arena of Contestation of Capitalism and Socialism}

Ownership as an arena for the contestation of Capitalism and Socialism is 
divided into two types, namely private or group ownership and public ownership. In the capitalist system, ownership of the means of production is controlled by individuals or groups, so that private ownership and recognition of property rights are the main characteristics of Capitalism (Zimbalist, 1988). Whereas in the Socialist system private ownership is considered to limit the potential of the productive forces in the economy. With no need for capital accumulation and a class of owners, private property in the means of production is considered an outdated form of economic organization which must be replaced by free association of individuals based on public or common ownership of these socialized assets (Engels, 2010).

In Fahrenheit 451, every citizen is narrated to have the freedom to have something according to his wishes. There is freedom to choose work, school and property. This matter described by Bradbury through a narration about the existence of various types of work, ranging from firefighters, drivers, police, teachers, students, housewives as the characters in the novel. In addition, the display of large advertising billboards is a description given by Bradbury how everyone in Bradbury society has the right to manage their finances, choose, and own things (Bradbury, 1983, p. 7). With the existence of freedom and progress in terms of trade which is marked by the development of commercial advertising, Bradbury seems to show that the people in Fahrenheit 451 are people who live in a free economy. This is emphasized again by Bradbury through the high demand for tertiary needs such as large televisions that fill the walls of the house which is also a societal trend in Fahrenheit 451. The view on the importance of television ownership is represented by Mildred, Guy Montag's wife, who continues to demand Montag to use 1/ 3 of his salary, two thousand dollars, to buy the 4th Wall-TV in his house (Bradbury, 1953, p. 15). The market competition caused by the consumptive lifestyle of the people gives the impression that the economic flow in the people at Fahrenheit 451 is going well. Bradbury shows that ownership of capital and property is the right of everyone, and this according to Zimbalist is one of the characteristics of Capitalism (Zimbalist, 1988).

Although Bradbury narrates the freedom of ownership over the individual, Bradbury also illustrates in his novel the control and power of ownership by the government. Although the people in Fahrenheit have rights to own something, the government keeps close looks on everything to make sure that everything in under the government's control, like television programs and news, education system and sole control over the legal apparatus, namely firefighters, police and teachers by the authorities.

Government's control in Fahrenheit 451 also includes television and radio programs identified with Mildred who every day of her life only has an interest in watching TV and listening to the radio. "The living-room; what a good job of labeling that was now. No matter when he came in, the walls were always talking to Mildred (Bradbury, 1983, p. 42)." Entertainment programs make the viewers portray the characters in his TV program as their family and in that family they find their world. The world Montag's wife lives in with Montag becomes a fictional world because there is no communication between the two. On the other hand, life on television with characters he refers to as "family" is real life. Mildred's obsession with electronic media cannot be separated from the influence of the 
government that provides access to the media, "the new medium of television promoted middle-class cultural values as normative through commercials and family-oriented shows. In The Dark Ages, no single force has as much effect in socializing with Americans in shaping tastes, habits by smoothing regional and ethnic differences as television. By diverting people's attention to electronic media, the government in Fahrenheit 451 creates a barrier between citizens and even intervenes in family communication. The inability of society in the novel Fahrenheit 451 to communicate or socialize, makes society compartmentalized in their respective activities and thoughts. They don't realize or care about the world outside them, so they don't know government programs. They have no other choice but to accept the government's recommendations and regulations. This makes it easier for the government in this novel to control the people.

The mastery of television as a mass media as well as a medium of information is also described in the novel The Hunger Games. The government controls the mass media through censorship and propaganda. The annual battle of 'The Hunger Games' which is considered an annual festival for the citizens of the 'Capitol' is broadcast live through television, as a censor of the resistance of the district residents to the arbitrariness of the 'Capitol', as well as propaganda of the absolute power and power of the 'Capitol' against the citizens. district by destroying their children in a life-and-death struggle but is considered a festival by the 'Capitol' (Collins, 2005, p. 19).

In contrast to Bradbury's narration in Fahrenheit 451, where individual ownership is still permitted by the government, Collins, like
Atwood in The Handmaid's Tale, provides a minimalist narrative of individual ownership in The Hunger Games novels. Every citizen in the district had almost no ownership whatsoever. Instead, the residents of this district have been exploited for their strength for the benefit of the rich Capitol community. This is in accordance with what was said by James (2000) that in general, Capitalism as an economic system and mode of production includes the accumulation of capital, namely production for profit and accumulation as an implicit goal of all or most of the production; narrowing or eliminating production previously carried out on social or private household grounds; commodity production i.e. production for exchange in the market and for maximizing exchange value-not value in use, and private ownership.

Government's control over the people in Fahrenheit 451 can also be recognized through its control over the legal apparatus like firefighter and police. In Fahrenheit 451, firefighters are used by the state as a means of executing power. It can be seen from the shifting of their functions from extinguishing fires to starting fires. Their tasks are set clearly at the very beginning, "Established, 1790, to burn English-influenced books in the Colonies. First Fireman: Benjamin Franklin." RULE 1. Answer the alarm swiftly. 2. Start the fire swiftly. 3. Burn everything. 4. Report back to firehouse immediately. 5. Stand alert for other alarms (Bradbury, 1953, p. 32)." By referring to Benjamin Franklin, the intention of manipulating information is obvious as if Franklin agreed to the firefighter's job description. Bradbury mentions Franklin here to refer to the Union Fire Company, also known as Benjamin Franklin's Bucket Brigade, which was a voluntary firefighting organization formed in 1736 (Chaplin, 2007). 
Unfortunately, in this novel, Beatty is portrayed by Bradbury as distorting the history of the firefighting organization which was originally formed to extinguish fires. In addition to controlling the fire department, Bradbury in Fahrenheit 451 narrates another major institution controlled by the government is the police. The police, who are supposed to protect the public interest, is used by government to pass the state's interest, namely securing the burning of books as a censor of knowledge to the public. This can be seen from the burning of a book owner who tried to defend his books (Bradbury, 1983, p. 34).

The security officers, who were given the name "Angel" which, when referring to the Bible as "protectors", were transformed by the government into "guardians" for the government's purposes, namely ensuring the compliance of the handmaids. Thus, the control of the state apparatus is also described by Atwood in the novel The Handmaid's Tale. The control of the state apparatus is also narrated by Westerfeld in Uglies. Through "Special Circumstances" who claim to be the guardians of the city's security and stability for the welfare of the entire community, but who actually act as executors to ensure that everything goes according to the government's plan and provide punishment for lawbreakers, namely for those who refuse to serve plastic surgery and choose to live freely outside the system (Westerfeld, 2005, p. 107). Like the malfunctions of the police in the Fahrenheit 451, Special Circumstances are also used by the government to hunt down and destroy people who are considered dangerous. The same thing goes with "Angels" in The Handmaid's Tale and in The Hunger Games The "Peacekeepers" which become extensions of the government to control and punish the disobeyed citizens. Thus, government ownership of vital state organs, in this case the police or security guards, is narrated in American dystopian novels.

In addition to the fields of communication and security, the governments described in the Dystopian novels also control education and manipulate knowledge. The government intends the public to be uneducated or uncritical, so it is easy to fall prey to public propaganda. Schools are used by the authorities to manipulate historical knowledge in accordance with the government's desire so that the younger generation records history that is actually not correct. Knowledge that is inhibited and blocked by dominating the school is a form of Capitalism that appears in Fahrenheit 451, The Hunger Games, and Uglies. By mastering the school, the ruler can launch propaganda to create compliance because the knowledge people have is limited and controlled. Strong government intervention is indeed a feature of Capitalism which is increasingly spreading in the Western world (Hyman and Baptist, 2014). Bradbury, Westerfeld, and Collins seem to attach great importance to government intervention, thus embodying this in their novels. Schools, which seem to enhance young generations' knowledge, are just covers to make people believe that citizens have rights to be knowledgeable. The facts are the schools either focus on students' pleasure like only giving Physical Educations, comic books, and movies like in The Fahrenheit 451, or became tools of propaganda by giving false information like in Uglies and The Hinger Games.

In the 1900s and 2000s, books were an important part of society. In Fahrenheit 451, all books except comics and books about sex are burnt. In Uglies, old books that are no 
longer allowed to exist in society are destroyed or burned by the new government (Westerfeld, 2005, p. 202). Both Bradbury and Atwood mention about 'knowledge is power'. Thus, people who have books will be knowledgeable, and have the potential to have power or power. Burning books can be interpreted as an effort to inhibit people from being knowledgeable, so that they do not have power. The government as the sole of power in these dystopia novels suppress to maintain obedience and control in society by banning people to be knowledgeable.

In addition to schools, the government in the novel Fahrenheit 451 is also described as controlling health institutions like hospitals as public facilities. In Fahrenheit 451 government provides two machines to cope overdose cases as the number of people committing suicides as the result of mental stress is increasing. a common case in society in novels, and therefore the government has prepared two machines to deal with this. Instead of preventing the stress faced by its citizens, the government with its property prefers to deal with the problems that arise as a result of this pressure (Bradbury, 1983, p. 13). The same thing about mastery of ownership in the health sector is also expressed by Atwood in The Handmaid's Tale. Given the privilege of examining the health and fertility of handmaids, and of keeping records of their health, the doctors take advantage of their position to abuse these women, with the desire to have sexual intercourse with them and to give the lure of pregnancy as pregnancy is the only thing that can saved these handmaids for further punishments (Atwood, 1985, p. 52).

In a capitalist system, property is supposed to be privately controlled, and the government protects private ownership rights to property, without government interference (Zimbalist 1988). But what happens is that private ownership of property is allowed, but remains under state control. What happened in Fahrenheit 451, The Handmaid's Tale, Uglies, and The Hunger Games is in line with the Marxist thought that the state controls the main sectors of the economy such as production, health care to be returned to the public interest (Horvart, 1982). However, in the world of Dystopia Fahrenheit 451, this Marxist thought does not apply fully because the government's control over public property is not used for public purposes, but as a means of public control to obey the government. This kind of depiction is well described in the novel Animal Farm, where control of public facilities and property is only enjoyed for the benefit of certain groups namely the rulers, who are depicted by pig characters, while other animals only contribute to production and not results. Socialists view the relationship of private property as limiting the potential of the productive forces in the economy. According to socialists, private property becomes obsolete when it concentrates on centralized and socialized institutions based on the appropriation of private income, but based on cooperative cooperation and internal planning in the allocation of inputs, until the role of capitalists becomes redundant (Wolff, 2014). With no need for capital accumulation and a class of owners, private property in the means of production is considered an outdated form of economic organization which must be replaced by free associations of individuals based on public or common ownership of these socialized assets (Engels, 2010). In these American dystopian novels, although the government allows the ownership of individual property, this individual and public ownership is controlled by the government. 
Thus, there are ideological contradictions between Capitalism and Socialism in this novel.

\section{Class System in Society as an Arena for the Contest of Capitalism and Socialism}

The next thing that becomes the arena for the contestation of Capitalism and Socialism in American dystopian novels is the class system. In Marxist theory, the capitalist stage of production consists of two main classes: the bourgeoisie, that is, the capitalists who own the means of production, and the proletariat or working class, which has to sell their own labour-power. It is the fundamental economic structure of work and property, a condition of inequality normalized and reproduced through cultural ideologies. Thus, the proletariat is forced into a position of subservience by the forces of capital, which have stripped the means of production from branding (Andrew, 1983; Breisser, 2001). In contrast to the class system built on the ideology of Capitalism, Socialism puts forward a classless society. Classless society refers to a society in which no one is born into a social class. Such differences in wealth, income, education, culture or social networks may arise and will only be determined by the experiences and achievements of individuals in such societies. In societies where class has been abolished, it is usually the result of a voluntary decision by the membership to form such a society to abolish the pre-existing class structure in society. The abolition of social classes and the establishment of a classless society are the main goals of libertarian Socialism (Beck, 2007). In American dystopian novels, the class system conflict is raised by the authors of dystopian novels in their novels.
In Fahrenheit 451, Bradbury shows the division of the class system, although the depiction is done explicitly. In the narrative of the story, the government in Fahrenheit 451 tries to abolish the class system by controlling all public facilities and giving equal treatment to everyone. The government drives people's thinking with the same ideology, by blocking access to knowledge through burning books and blocking information, so that people are directed to an understanding that has been controlled by the government, feels they are in the same social class, and already lives in happiness. "Then they'll feel they're thinking, they'll get a sense of motion without moving. And they'll be happy, because the facts of that sort don't change. Don't give them any slippery stuff like philosophy or sociology to tie things up with." (Bradbury, 1983, p. 58).

However, Bradbury in his novel does not really present a classless society, which characterizes the ideology of Socialism. On the other hand, with an authoritarian government, in which every citizen was forced to follow the rules, Bradbury produced a class system in Fahrenheit 451. The bourgeoisie in Fahrenheit 451 was hidden from the ordinary proletariat, behind its agents, the firefighters. The government consciousness at Fahrenheit 451, emphasized the distance between the bourgeoisie and the proletariat and focused the tension between the people. In the novel, the firefighters are used as a "repressive structure". Firefighter is used as a method of control by supporting and spreading dominant class ideology.

Similar to Fahrenheit 451, The Handmaid's Tale depicts the social struggles of various classes in a Dystopian world where politics and the rank and power of different classes are considered important. In this case, 
Atwood in The Handmaid's Tale divides the class system into three, namely the upper-class system who gets higher opportunities and positions and can own goods that should be prohibited by the government, middle class society represented by professional workers such as doctors, lawyers, writers, whose job is to serve the upper class, and the lower class system, i.e., lowly, unskilled workers. Underneath all that, are women, who are further classified according to their social class, namely the wives of officials, handmaids, maids, and unwomen.

From the beginning of the novel, the division of women according to their social class is obvious. "At the bottom of the stairs there's a hat-and-umbrella stand...There are several umbrellas in it: black, for the Commander, blue, for the Commander's Wife, and the one assigned to me, which is red (Atwood, 1985, p. 15)." Thus, colours distinguish people from one another.

As the story progresses in The Handmaid's Tale, differences in social class can be in the description of houses, cars and some characters that represent class in society. This shows how Capitalism works and other people are exploited according to capitalist interests. Althusser believed that Capitalism seeks to produce maximum commodities at the lowest prices and highest profits. Naturally, this is in line with the increasing exploitation of labour (Althusser, 1971).

The economy has always been an effective weapon for the ruling class to maintain their position in society. By exploiting the ignorance of the dominated class, rulers make other classes look inferior so that they can claim power and be responsible for work and labour (Althusser, 1970). The handmaid also stands as a symbol of the proletariat, subjugated by the bourgeoisie to the point of slavery, violently indoctrinated in a psychologically destructive way, and denied its basic freedoms. In Atwood's novel, The Handmaid's Tale, Offred experiences his daily life under a bourgeois theocratic regime ruled by religious fundamentalists. The commanders are the system leaders. The experience of this female servant reveals the gap or rather the true character of the religious readers in her society or rather the true picture of the people who will become the maidservants. He will spend his life in service and devotion to the spiritual leaders of the Republic of Gilead who are representatives of God. Gilead's bourgeois society can be observed using religion in such a way as to achieve political control over the proletariat which it may lack. Lois W. Banner points out that religion has long been used as a means of controlling population (Banner, 1973). It is an effective political tool cloaked in scriptures, sacraments, and other dogmatic devices that deceive the devout into believing and following a dogma.

Westerfeld in Uglies presents the class system opposition of Socialism and Capitalism. In order to create a classless society, the government in Uglies requires all teenagers to undergo plastic surgery on their 16th birthday. By leading up to plastic surgery at the age of 16, Westerfeld is actually that the class system is narrated in Uglies. Uglies are described as a group of people who are quarantined in separate places, with limited access, and low social status. While Pretties are people who have successfully undergone plastic surgery and have the right to live in luxury, pleasure, and the sufficiency of the necessities of life. Unlike the previous two novels, in Uglies, Westerfeld does not mention the domination of the class, or the Pretties, 
over the lower class, the Uglies. This is because the control that is highlighted in this novel lies in the ruler or government, which is outside the life of the people of these two classes.

Different from the previous dystopian novels, in The Hunger Games, Collins directly divides the Panem people into two class systems, namely rich to poor. The richest are those who live in the Capitol, while the poorest are those from the District. The higher the district number, the poorer the condition of the district. The Capitol represents the bourgeois Capitol which owns the means of production employs wage laborers and controls the state, and is the ruling class, while the district represents the proletariat (workers) which is defined as a class that does not own the means of production, and owns nothing but its labour-power. The people of the Capitol lived in luxury and freedom, while the people of the district were poor and oppressed.

In these American dystopian novels, there is a class system conflict in the arena of Capitalism and Socialism. Although initially the ruler intended to create a classless society, as narrated in Fahrenheit 451 and Uglies, the class system still exists in the narratives of these novels. The Dystopian society in these novels is divided into two major groups, namely the bourgeois class or the dominant class in control, and the proletariat class which is under the bourgeois class.

\section{Exploitation as an Arena for the Contest of Capitalism and Socialism}

Exploitation refers to the act of taking advantage of others without giving them fair compensation. Exploitation is common in Capitalism. Exploitation has become a feature of all class society, which is divided into two main classes, the exploited class which produces wealth and the exploiter class which takes over it. Under Capitalism, most needs are met, at least for those who can afford them, with commodities being goods and services produced for sale in the market. Working class people, who do not have the means to produce and sell commodities, have one commodity they can sell: their labour, their ability to work. In this way, workers are forced to sell themselves to some parts of the capitalist to get money to buy necessities of life. On the other hand, Socialism does not carry the principle of exploitation. Socialists apply the principles of equality, democracy, individual freedom, self-realization, and community or solidarity. Regarding equality, they have proposed a strong version of the equality of opportunity principle according to which everyone should "broadly have equal access to the material and social means necessary to lead a thriving life" (Wright, 2010).

In Fahrenheit 451's own novel society, that exploitation exists in the form of mass exploitation. In particular, society is subtly exploited by the government which manipulates its people to do things that can benefit the government, namely the mass media provided by the government which continues to feed the public with false information that deceives people into doing the government's dirty work without any complaints. The government in the novel Fahrenheit 451 tries to brainwash its people and manipulate them into believing that knowledge is not needed by society and does not guarantee their happiness, but that obedience and submission to all government decisions is the best way to obtain happiness.

The exploitation that Atwood clearly narrates in his novel, The Handmaid's Tale. 
Through this novel, Atwood explores the female body in the economic exploitation of women. Patriarchs in the Republic Gilead isolated the women and then transferred them to domestic suburbs. In the Republic of Gilead, humans are not equal, not all men are first class citizens because some men are second class citizens, but all women are third class citizens. To reaffirm male dominance in the Republic of Gilead, men control women who are judged to be potentially threatening and subversive. In this novel, women are laid off from jobs which refer to their independence to be independent with their own income, prohibited from owning property or accessing assets, and made virtual prisoners in their homes. The imprisonment of women paved the way for the Gilead institution for a class system, with clear standards of behaviour, dress, and responsibility. However, as in all Dystopian societies, this class system is actually an instrument of oppression, especially for women.

As told by Atwood in The Handmaid's Tale, Collins in The Hunger Games also exposes the exploits of the Capitol to the districts. Panem is divided into thirteen districts where each district is required to surrender most of its wealth and products to the government located in the Capitol. The people in the districts suffer from poverty and destitution coupled with the fear of making the typology of power in The Hunger Games called Lucks includes power, authority and manipulation. The Capitol is described as a large city located in the Rocky Mountains centred on 13 districts, the number of districts in which the country was formed. There, people lead a prosperous life and provide them with a luxurious lifestyle. They indulge in choices in life that offer a variety of exotic foods and fashionable clothes. Meanwhile, people in the district live on little food. The balance of power works exclusively in favour of the capital which enjoys all the prerogatives as a result of the concentration of power, while the other districts lag behind in all aspects of life. Exploitation is carried out massively through the game "The Hunger Games", which involves twenty-four young people from the districts in a bloody game at stake for their lives, in exchange for "tessera", which is the staple material for the survival of their families (Collins, 2008, pp. 13-4).

This bloody game that was broadcast live on television, in which parents were forced to watch their children killed in this brutal way caused fear and trauma to the district residents. District people have undoubtedly given in to the government on the one hand and, just as importantly, they have developed a government phobia, a fear that makes them unable to resist or even have time to resist. In "Discipline and Punishment: The Birth of the Prison" (1977) Foucault explains that if the economics of exploitation separates power and products from work, it can be said that disciplinary coercion establishes within the body the linking relationship between increased proficiency and increased dominance (Foucault, 1977). The Capitol maximizes the exploitation of physical strength through the continuous work the district residents have to do and also through The Hunger Games. Anyone who violates government laws. According to Sarah Collinson, because the identity and wealth of the district residents were violated, they were vulnerable and powerless, therefore the Capitol dominated the district and severely punished them for taking their products and identities. Power and powerlessness determine the distribution of access to food and other key commodities and assets between and within 
different groups. Those who lack power cannot protect their basic political, economic and social rights, and may not be able to protect themselves from violence. The exploitation of the district residents is not only physical, but also psychological, that is, psychologically controls and infiltrates human existence and keeps it from its basic psychological balance, thereby separating humans and even dividing humans from themselves. Dividing humans separately, psychologically, makes humans weak and unable to carry out a revolution.

Thus, in American dystopian novels, American authors put forward the narrative of exploitation as one of the hallmarks of Capitalism. The weak are exploited by the strong for the benefit of the strong, while the weak are increasingly being oppressed and get nothing. This exploit that characterizes Capitalism is recounted in Fahrenheit 451, The Handmaid's Tale, and The Hunger Games.

From the explanation above, Capitalism and Socialism are two ideologies that are consistently narrated by the authors of American dystopian novels in their dystopian novels. In the conflict between Capitalism and Socialism, the arena of contestation lies in property, class system, and exploitation. In the ideology of Capitalism, ownership is controlled and used for personal or certain group interests, while in the ideology of Socialism, ownership is for the benefit of the people.

\section{CONCLUSION}

Through this study, American dystopian novels confirm the application of the ideology of Capitalism which refers to the control of property by the rulers, class differences in society, and exploitation as proposed by Zimbalist (1998). The thought of Capitalism was originally closely related to American conservative utopian thinking. This utopian writer believes that America is the role model of the world and therefore American Capitalism should be spread throughout the world. Dystopian literature, which is often said to contain criticism of society may present the idea of Capitalism as a critique and satire on the practice of Capitalism in America.

By confirming the ideology of Capitalism, American dystopian novels negate the ideology of Socialism which refers to equality, equality, and the absence of a class system as advocated by Wright (2010). Dystopia which is often said to be anti-Utopia should negate capitalist ideas and be open to socialist ideas. But in American dystopian novels, this is negated. In fact, Dystopian novels re-emerge the ideas of Capitalism which are implemented by authoritarian governments.

\section{REFERENCES}

Althusser, L. (1984). Essays on ideology. Verso.

Baptist, E. E \& Hyman, L. (Eds.). (2014). American capitalism: A reader. Simon \& Schuster.

Boldizzoni, Francesco (2020). Foretelling the End of Capitalism: Intellectual misadventures since Karl Marx. Harvard University Press

Braudel, F. (1982). The wheels of commerce: Civilization and capitalism $15^{\text {th }}-18^{\text {th }}$ century vol 2 ( $^{\text {st }}$ ed.). S. Reynold (Trans.). Harper \& Row.

Busky, Donald F. (2000). Democratic Socialism: A Global Survey. Praeger. p. 2. 
RUBIKON Volume 8/ Number 2

September 2021

Burt, N. (1999). The perennial Philadelphians: The anatomy of an American aristocracy. University of Pennsylvania Press.

Mark, J. Perry. (2016). Why Socialism always fails? https://www.aei.org/carpediem/why-socialism-alwaysfails/?utm_source

Marx K. (1993). Grundrisse: Foundations of the critique of political economy. $\mathrm{M}$. Nicolaus. Penguin Books.

Wolf, M. M. (2014). Shaping globalization finance \& development. International Monetary Fund. 51(3), 2225.

Wright, R. (2000). Nonzero: The logic of human destiny. Pantheon Books

Zimbalist, A. \& Sherman, H. J. (1988). Comparing economic systems: A political-economic approach. Harcourt College Pub. 